Article

\title{
Locating and Mapping the Traces of the Covered Ancient Theater of Amphipolis (Eastern Macedonia, Greece)
}

\author{
Dimitris Kaimaris ${ }^{1, *}$, George Karadedos ${ }^{2}$, Charalampos Georgiadis ${ }^{3}$ and Petros Patias $^{4} \mathbb{D}$ \\ 1 School of Spatial Planning and Development (Eng.), Aristotle University of Thessaloniki, \\ GR-54124 Thessaloniki, Greece \\ 2 School of Architecture, Aristotle University of Thessaloniki, GR-54124 Thessaloniki, Greece; \\ gkaradedos@gmail.com \\ 3 School of Civil Engineering, Aristotle University of Thessaloniki, GR-54124 Thessaloniki, Greece; \\ harrisg@civil.auth.gr \\ 4 School of Rural \& Surveying Engineering, Aristotle University of Thessaloniki, \\ GR-54124 Thessaloniki, Greece; patias@auth.gr \\ * Correspondence: kaimaris@auth.gr
}

Received: 16 September 2018; Accepted: 23 October 2018; Published: 1 November 2018

check for updates

\begin{abstract}
Ancient Amphipolis (Eastern Macedonia, Greece) is one of the most important archaeological sites of Greece. Despite the restricted excavation studies, important monuments have been discovered, such as the city walls and the Macedonian burial site at the Kasta hill, etc. Currently, the location of the ancient theater is unknown and only assumptions can be made regarding its location. In the current study, we aim to detect the accurate location of the ancient theater using archaeological prospection tools, data collected from the excavated sites, and testimonies of people of the modern city. For the first step of the approach, the approximate location of the ancient theater was determined using information derived by archived geospatial data (multi-temporal aerial photographs, satellite image, and Digital Terrain Model (DTM) of the area) as well as information regarding the neighboring excavated sites. For the in-depth study of the area of interest, a drone was used for the acquisition of high-resolution geospatial data. The generated orthorectified image ( $3 \mathrm{~cm}$ spatial resolution), DTM, and Digital Surface Model (DSM) allowed the determination of the potential location of the buried orchestra's center using geometric rules for the design of ancient theaters. Furthermore, using the produced DSM and DTM, terrain cross-sections were generated.
\end{abstract}

Keywords: Amphipolis; ancient theater; drone; orthorectified image; DSM; DTM; terrain cross-sections

\section{Introduction}

The ancient city of Amphipolis is built in the place of the Thracian tribe of Idonon's older

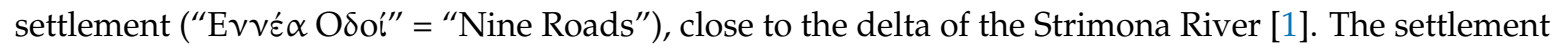
is reported by Thucydides [2], Stravonas [3], and Herodotus [4]. Recent archeological studies revealed the existence of buildings older than Amphipolis, upon which the north wall (constructed during the classical era) of the city was build [5]. This study verifies the Thucydides writings, which mention: "residents of the city of Amphipolis with the previous name Nine Roads" [2].

Amphipolis' geographic location caught the attention of Parians, Thasians, Andreions, Chakideons, Milisions, and later on the attention of the Athenians and Spartans. Its location was a strategic and economic node because it gave the opportunity to control the land access to the Thracian mainland—which was rich in resources (ship construction timber, ore deposits)—from the coastal area, 
as well as the maritime transport originating from Thasos (an island $70 \mathrm{~km}$ to the east, southeast of Amphipolis), Chalkidiki, the Aegean Sea islands, and Hellespont.

The Parians were the first that realized the strategic and economic importance of Thasos and the Thracian coasts in the beginning of the seventh century B.C. They colonized Thasos Island, lead by Telesikli. Around 660-650 B.C. they started colonizing the coastal area of Thrace, along with the Thasians, and established the city of "Peraia" or "Ipeiros Thasion". After fierce battles with the Thracians, they started building fortified cities in the vicinity of "Nine Roads", such as Galipsos, Oistimi, Neapolis (Kavala), Strimi, and later on Krinides, which was renamed Philippoi by Philippos II. The income of Thasos due to mining operations reached 200 to 300 talanta, giving the island the ability to build a powerful military naval force and establish trading routes [5].

The Athenians started to get interested in the area from the time of the Peisistratus' exile (at the end of the sixth/beginning of the fifth century B.C.), who were amassing resources (funds and mercenaries). Thrace and Eastern Macedonia were temporarily conquered by Persians during the expedition of King Darius to South Greece. Following the defeat of the Persians, Thasos became a member of the first Athenian Alliance in 477 B.C. The Athenians' attempt to conquer the Peraia of Thasos and the Paggaio Mountains forced the Thasians to leave the alliance. Kimon forced the Thasians to surrender after a three-year siege of the city, enforcing the abandonment of the Peraia mines [5].

The expansion of the Athenians in the area (focusing on the control of the silver and gold mines of the Paggaio Mountains) started with the conquest of Hionas in 476 B.C. In 465 B.C., an expeditionary force of approximately 10,000 colonists lead by Leagro and Sofani conquered "Nine Roads". Unfortunately, when they attempted to enter the Thracian mainland, they were decimated by the Thracian tribe of Idonon at Dravisko. In 437 B.C., the Athenians storming from Hionas repelled the Thracians and, with new colonists lead by Agnona, set foot in the area and began to build the city of Amphipolis in the location of "Nine Roads" [2].

The Spartan general Vrasidas occupied the city of Amphipolis in 424 B.C., provoking an attitude of awe toward the Athenians mainly because of the strategic and economic importance of Amphipolis [2]. Despite three attempts of the Athenians to regain Amphipolis, the city remained independent until its occupation by the Macedonians. In 358-357 B.C., Philippos II occupied Amphipolis after a sudden attack [5] and used it as a base to conquer the wider area east of the Strimona river. During the Hellenistic era-up to the battle of Pidna in 168 B.C., when the Romans occupied the state of Macedonia-Amphipolis was the center of exploitation of all the mines in the area, an important commercial center, one of the most powerful royal mints of Macedonians, a powerful fortress of great military importance, and a naval base of Alexander the Great, from which his fleet started the expedition to the East. Amphipolis, in which the three more important admirals (Nearchos, Androstehis, and Laodemon) under the command of Alexander the Great lived, was one of the six cities where a magnificent temple costing 1500 talanta was going to be built under the command of Alexander the Great (the Macedonian burial site at the Kasta hill) [6].

Following the conquest of Macedonia by the Romans, Macedonia was divided into four administrative regions. Amphipolis (conquered by Aemilius Paullus) was the capital city of the first region [3]. Aimilios-Paylos established athletic games that took place yearly with the participation of Greeks and foreigners from Greek and Asian cities.

The crossing of Via Egnatia through Amphipolis helped to maintain its strategic and economic importance in the Roman and early Christian periods.

Taking into account the abovementioned facts and the quality of the structures found at the excavated sites, one can assume that the theater of Amphipolis, which reflected the social life of this important city, would be as important as Amphipolis. An indication related to the importance of the theater is the discovery of a clay tile demonstrating the faces of actors in a tomb at a cemetery dating from the Hellenistic period [5].

The Amphipolis' ancient theater is expected to be of equal importance to that located in the city of Philippoi, since it had the same historical evolution and importance. In addition, the political and 
economic importance of Amphipolis was greater through the Hellenistic and Roman periods [5]. Following the information acquired from the other ancient theaters of Thrace, such as those in Maroneia [7], Thasos [8], and Philippoi [9], it is expected that this theater will also have later Classic, Hellenistic, and Roman phases. Furthermore, the discovery of an elaborate Roman lion-foot, which has not been discovered in the other theaters, reveals that during its Roman phase the Amphipolis' theater was at its peak. In addition, during the Roman period, gladiator duels and beast-related spectacles were very popular in the wider area, suggesting that the Amphipolis' Theater might have been transformed into an arena, as was the fate of other existing theaters in the area of Thrace [5].

The use of aerial images (aerial archaeology) in archaeological studies has its roots in the beginning of the 20th century, while satellite images (remote sensing archaeology) have been used for the same reason since the 1970s. Currently, state-of-the-art platforms equipped with digital sensors such as autonomous Unmanned Aerial Vehicles (UAVs) and satellites are employed. A variety of digital sensors, for instance panchromatic, multispectral, hyperspectral, thermal, lidar, and radar, are used for the qualitative and quantitative documentation of known archeological sites or for the detection of unknown ones. All the above are employed in conjunction with traditional field work to help archaeologists [10-18].

Using a drone equipped with a modern digital $18 \mathrm{Mp}$ resolution camera allows the three-dimensional (3D) mapping of an archaeological site with a spatial resolution of 1-2 cm [19]. The appearance of marks on the ground or on the vegetation are caused by the interaction of a buried monument (a "concrete construction", e.g., the boundaries of a building, or an "open construction", e.g., an ancient trench) with the ground or vegetation [20,21]. In aerial and remote sensing archaeology, significant efforts are made for automatic detection, digital visual enhancement of marks in images, and interpretation of the phenomenon of interaction between buried monuments and the ground or vegetation, using panchromatic, multispectral, and hyperspectral sensors [11-13,21,22].

This study aims to pinpoint the location of the ancient theater of Amphipolis. In order to achieve this aim, the authors utilize tools of archaeological prospection and data from existing excavations that are combined with testimonies of the residents of Amphipolis. For the presentation of the ancient city of Amphipolis and the understanding of its geomorphology, various geospatial archived data-such as the Digital Terrain Model (DTM) of the wider area-are employed to discover the potential location of the ancient theater. In addition, recently acquired drone images are used to perform an in-depth study of the potential location.

\section{Methodology and Data Collection}

\subsection{Methodology}

The use of archived multi-temporal geospatial data of the study area can allow the detection of temporal marks of buried infrastructure/buildings, the topology of the specific site as well as geomorphological changes, the detection of changes in the ground coverage (e.g., bare ground to vegetation), and the spatial correlation of known monuments, etc. [20-28].

As a result, various multi-temporal geospatial data (historic and modern aerial photos, satellite images, etc.) covering the study area were gathered and studied.

Combining the abovementioned information with testimonies of the residents of Amphipolis, it is possible to minimize the spatial extent of the search area for the detection of the buried structure.

Following the study area definition, the data acquisition phase can be realized. The data acquisition involved a UAV for image acquisition and a Global Positioning System (GPS) for Ground Control Points (GCP) measurement. The data were processed using digital photogrammetric processing software. As a result, the area of interest can be quantitatively and qualitatively documented and studied in depth using the produced Digital Terrain Model (DTM), Digital Surface Model (DSM), and orthorectified image. 
In this study, a hexacopter drone was used for image acquisition, a TopCon Hiper SR GPS receiver was used for GCP measurements, and Agisoft PhotoScan ${ }^{\circledR}$ software was used for the photogrammetric processing of the acquired data.

Agisoft PhotoScan ${ }^{\circledR}$ is a standalone software product that performs photogrammetric processing of digital images and generates 3D spatial data. The processing in Agisoft PhotoScan ${ }^{\circledR}$ consists of the following steps: image alignment, dense point cloud generation, mesh generation (Triangulated Irregular Network (TIN) creation), DSM production, and ortho image generation.

During the image alignment step, which is focused on reconstructing a three-dimensional scene, the relative orientation between the images is reconstructed through the matching of tie points between them. If control points or other metric information is used, such as distances between points, the absolute orientation is also computed at this stage. The following processing step generates a dense point cloud of the area, thus creating a large number of points that complete the 3D model. The next step generates a mesh or a wire frame model by creating triangles between the points. Using the generated mesh, the DTM of the area is generated in the subsequent step. An optional step can generate a textured model using an image overlay $[29,30]$.

Finally, by exploiting the high-spatial-resolution DSM, one can determine the potential center of the buried orchestra using the geometry rules for designing an ancient theater on one hand, and create cross-sections in various directions on the other hand.

It must be noted that the findings of this study have the purpose of providing additional information to archaeologists and they can only be confirmed/documented by excavating the site.

\subsection{Archived Data}

During an older aerial and remote sensing archaeology study of the wider area between Amphipolis and Philippoi [20-28,31], various geospatial data of the study area were collected and processed. More specifically, black and white (B/W) orthorectified aerial images were obtained in 1945 (1:42,000 scale), 1983 (1:7000 scale), and 1998 (1:40,000 scale) (Table 1). In addition, an orthorectified QuickBird-2 image (4 bands: red, green, blue, near infrared) with a spatial resolution of $0.6 \mathrm{~m}$ acquired on 5 February 2005 was also used. Furthermore, the panchromatic orthorectified images and the DTM ( $5 \times 5 \mathrm{~m}$ grid) obtained in 2007, provided by the National Cadastre and Mapping Agency SA (Société anonyme), were also utilized.

Table 1. Multi-temporal data.

\begin{tabular}{cccccc}
\hline Data Type & Scale & Provider & Year & Product & $\begin{array}{c}\text { Spatial } \\
\text { Resolution }(\mathbf{m})\end{array}$ \\
\hline $\begin{array}{c}\text { Aerial } \\
\text { Photographs }\end{array}$ & $1: 42,000$ & $\begin{array}{c}\text { Hellenic Military } \\
\text { Geographical service }\end{array}$ & 1945 & $\begin{array}{c}\text { Orthorectified } \\
\text { image (B/W) }\end{array}$ & 1.0 \\
\hline $\begin{array}{c}\text { Aerial } \\
\text { Photographs }\end{array}$ & $1: 7000$ & $\begin{array}{c}\text { Hellenic Cartographic and } \\
\text { Cadastral Organization }\end{array}$ & 1983 & $\begin{array}{c}\text { Orthorectified } \\
\text { image (B/W) }\end{array}$ & 0.2 \\
\hline $\begin{array}{c}\text { Aerial } \\
\text { Photographs }\end{array}$ & $1: 40,000$ & $\begin{array}{c}\text { Directorate of Topography, } \\
\text { Ministry of Rural } \\
\text { Development and Food }\end{array}$ & 1998 & $\begin{array}{c}\text { Orthorectified } \\
\text { image (B/W) }\end{array}$ & 1.0 \\
\hline $\begin{array}{c}\text { Satellite image } \\
\text { QuickBird-2 }\end{array}$ & $-\quad$ DigitalGlobe & 2005 & $\begin{array}{c}\text { Orthorectified } \\
\text { image (B/W) }\end{array}$ & 0.6 \\
\hline $\begin{array}{c}\text { Aerial } \\
\text { Photographs }\end{array}$ & $1: 20,000$ & $\begin{array}{c}\text { National Cadastre and } \\
\text { Mapping Agency (NCMA) SA }\end{array}$ & 2007 & $\begin{array}{c}\text { Orthorectified } \\
\text { image (B/W) }\end{array}$ & 0.5 \\
\hline $\begin{array}{c}\text { Digital Terrain } \\
\text { Model }\end{array}$ & - & NCMA SA & 2007 & $\begin{array}{c}\text { Raster format } \\
\text { (B/W) }\end{array}$ & 5.0 \\
\hline
\end{tabular}

\subsection{Unmanned Aerial Vehicles}

The drone (Figure 1) is able to fly completely automated or controlled manually via remote control. It consists of the spindle, where the batteries and the digital camera are housed, and the ground station. 
The movement of the Unmanned Aerial Vehicle (UAV) is realized through six propellers. The camera gimbal (where the digital camera (DSLR Canon 1200D, with CMOS sensor (22.3 mm $\times 14.9 \mathrm{~mm}$ ), $18 \mathrm{MP}$ resolution using the Canon lens (EF-S 17-85 mm f/4-5.6 IS USM lens, focal length minimum-maximum: $17-85 \mathrm{~mm}$, aperture: $4-5.6$ ) is placed to allow its vertical rotation by 180 degrees ( \pm 90 degrees from the nadir). The digital camera self-calibration is performed during the image processing (in the corresponding photogrammetric image processing software, e.g., Agisoft PhotoScan ${ }^{\circledR}$ ). The UAV uses the autopilot Wookong M of DJI, which incorporates a Controller, an IMU, and a GPS. Its horizontal accuracy is approximately $\pm 2 \mathrm{~m}$, its vertical accuracy reaches $\pm 0.5 \mathrm{~m}$, and the angle measurement accuracy in the three axes ranges from approximately $1^{\circ}$ to $2^{\circ}$ (according to the specifications of the autopilot). The lifting capacity of the drone is $2.5 \mathrm{~kg}$, and the flight time ranges between 10 and $15 \min [32,33]$.

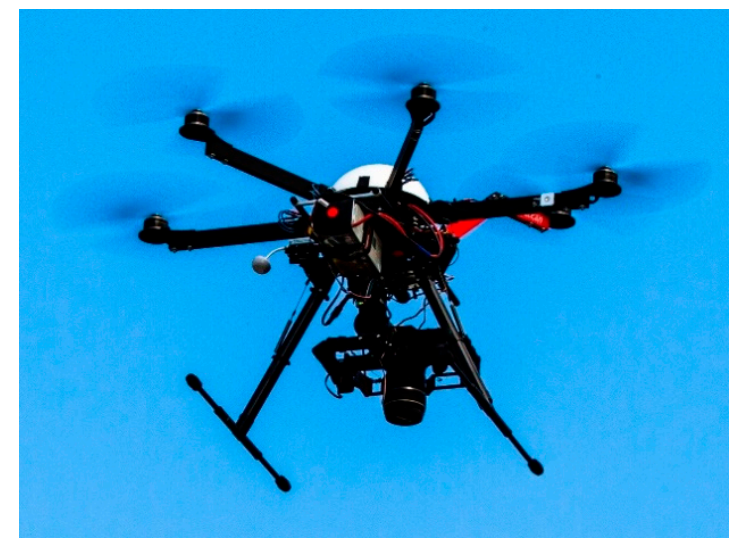

Figure 1. Drone.

\section{Results and Discussion}

\subsection{The Potential Location of Amphipolis's Ancient Theater}

Amphipolis is surrounded by the Strimonas River (south, north, and west), while in the east lies the Paggaio Mountains. Figure 2 presents the location of ancient Amphipolis, depicting the known archaeological excavation sites. The contour lines (6-m intervals) in Figure 2 were generated by the DTM provided by the NCMA (Table 1). The outer wall of the ancient city (Classical/Hellenistic periods; fifth to first centuries B.C.)) is drawn in black. The inner wall of the late Roman period (fourth to sixth centuries A.D.) is drawn in red. Within the inner wall, four basilicas, a central building, a reservoir, and parts of residential buildings (presented in red) of the same period (late Roman) exist. Southwest of the abovementioned constructions, Hellenistic period buildings can be found (presented in black), and to their south lie the Temple and the Gymnasium of the city. East of the outer wall, one can observe two locations of Macedonian burial sites (presented in blue) and the cemetery of the Hellenistic period (presented in black) [34-36].

According to information collected from the current residents of Amphipolis, seating stones were removed for the construction of modern-era buildings from the location north of the excavated site of Gymnasium, called "skalakia". This location is near to the city Temple.

Additional information regarding the location of the ancient theater of Amphipolis can be drawn from the study of the terrain relief of the ancient city (Figure 2) combined with the locations of already known structures, specially the locations of the Temple and the Gymnasium. More specifically, the only potential location of the ancient theater is located within the boundaries of the dashed circle in Figures 2 and 3, between the Gymnasium and the south part of the outer wall. The contour lines at this position (Figures 2 and 3) resemble the spatial morphological characteristics of an ancient theater's structure. 


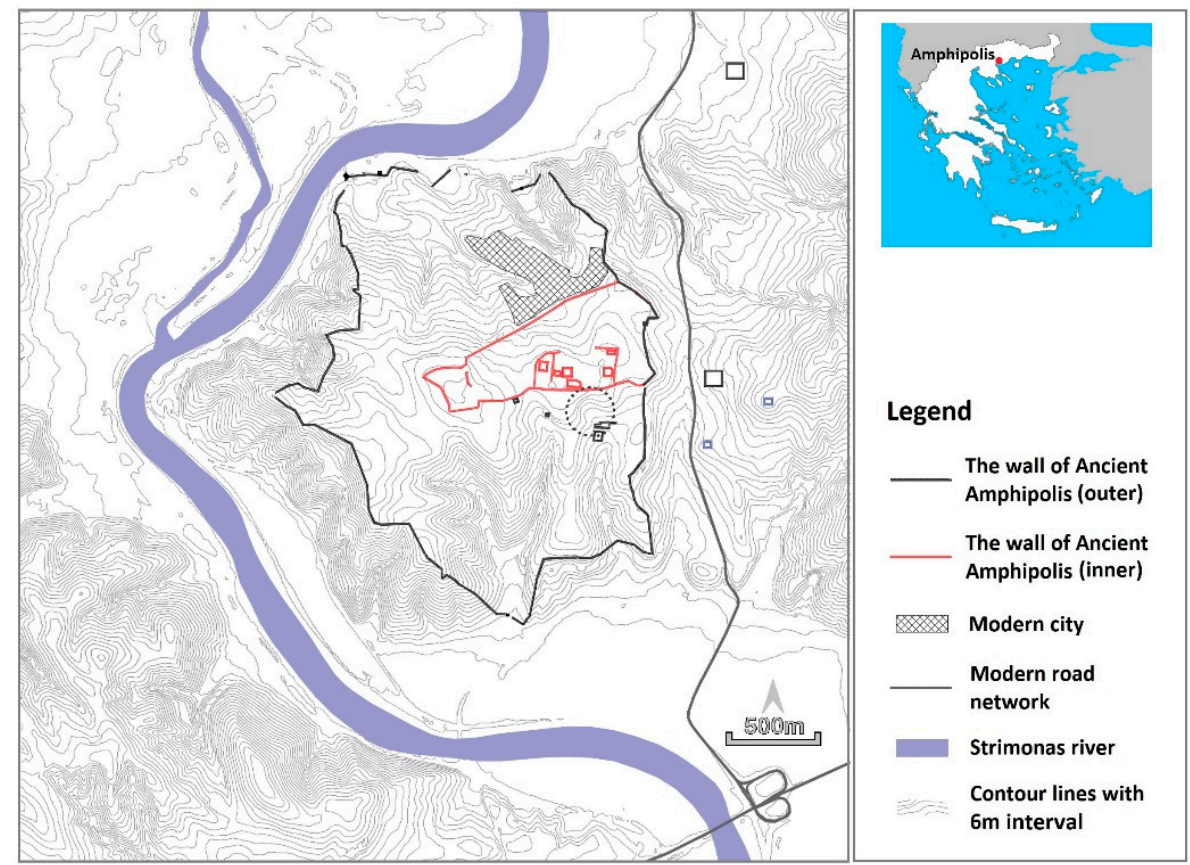

Figure 2. Map of ancient Amphipolis. The contour lines derived from the NCMA DTM were used as the base map. The absolute heights of the inner wall area range from $18 \mathrm{~m}$ to $152 \mathrm{~m}$ (latitude N: 40.81699881 and longitude E: 23.8430717 in decimal degrees at the center of the image, Reference System: WGS84).

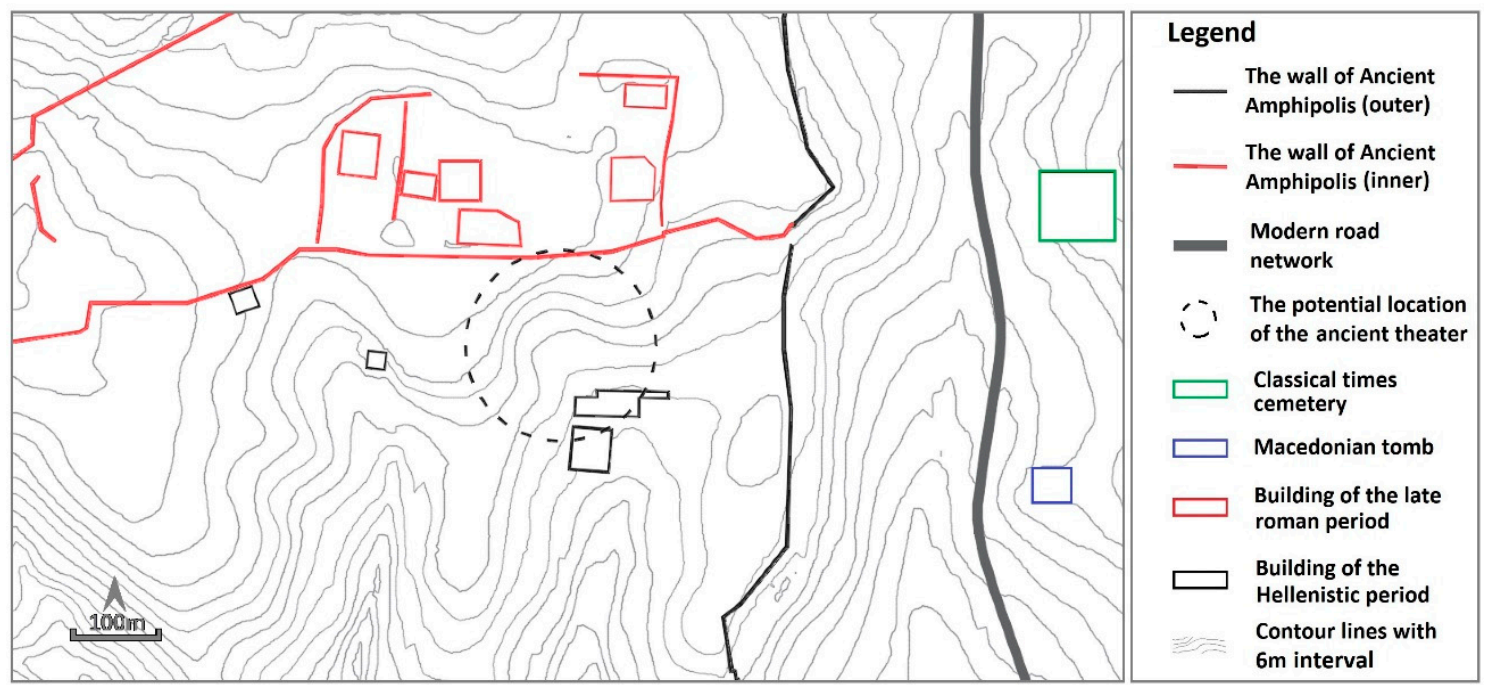

Figure 3. Detail of Figure 2 showing the area of the potential location of the ancient theater. Contour lines derived by the NCMA DTM were used as the base map.

Figure 4 presents the available multi-temporal data of the potential location of the ancient theater. Figure $4 \mathrm{a}$ presents the contour lines of the potential ancient theater location with intervals of $2 \mathrm{~m}$. In the center of Figure 4c (detail of the 1983 orthorectified image) lies the potential location of the ancient theater. Northwest of the location, above the southern inner wall, the excavated basilica is shown. To the south, the Gymnasium (323-31 B.C.) excavation site is presented. Finally, west of the location, the cover of a Hellenistic period building can be observed, while between the potential position of the theater and the Hellenistic period building one can observe negative vegetation marks [20], suggesting the existence of buried constructions (Figure $4 \mathrm{~d}$, shown in yellow). Figure $4 \mathrm{~d}$ shows the contour lines using the orthorectified image as a base map. 

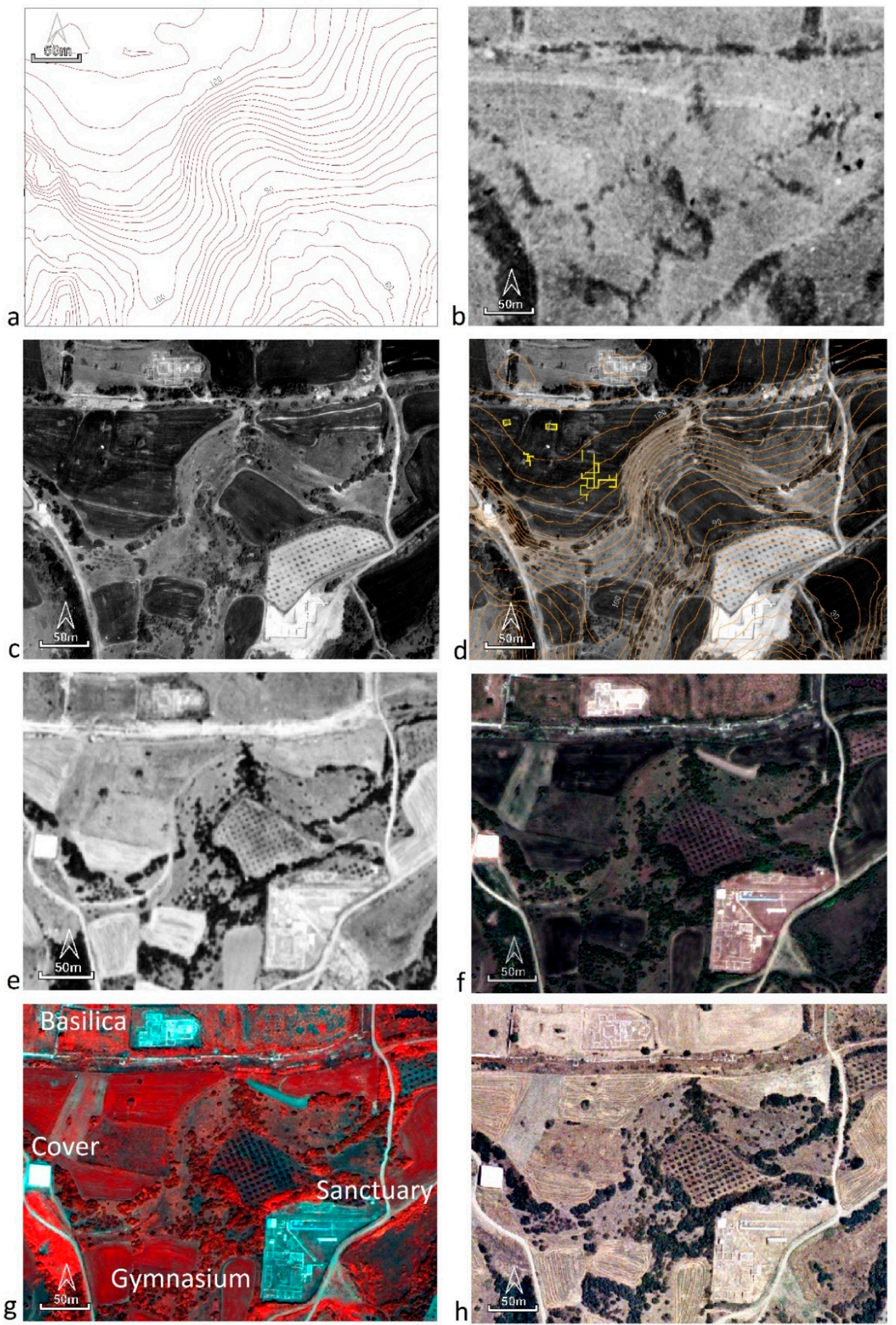

Figure 4. (a) The terrain relief at the location of the ancient theater using the 2-m interval contour line of NMCA 2007; (b) detail of the 1945 orth rectified image; (c) detail of the 1983 otho rectified image; (d) 1983 orthorectified image overlaying linear negative vegetation marks and contour lines (a); (e) detail of the 1998 orthorectified image; (f) detail of the 2005 orthorectified QuickBird (QB) 2 image (bands: red, green, blue); (g) orthorectified QB2 image displaying the names of buildings and presenting vegetation in red by exploiting the infrared band (bands: near infrared, green, blue); (h) detail of 2007 orthorectified image. 
The observation of Figure $4 \mathrm{~b}$ (detail of the 1945 orthorectified image) reveals that these locations have not been excavated and that one cannot distinguish the location of the ancient theater. In Figure $4 \mathrm{e}$ (detail of the 1998 orthorectified image), one can clearly see the expansion of the Gymnasium excavation and for the first time the emergence of the Sanctuary (north of and in contact with the Gymnasium site). The same applies for Figure $4 \mathrm{f}$ (detail of the 2005 orthorectified QuickBird-2 satellite image) and $3 \mathrm{~h}$ (detail of the 2007 orthorectified images). Figure $4 \mathrm{~g}$ presents the vegetation (in red) using the infrared band of the satellite image; the names of the mentioned locations are also presented.

It is obvious that at the potential location of the ancient theater, low plants were cultivated up to 1983, while from 1998 and onward trees were mainly cultivated (for this reason no new images after 2007 were used, as it is impossible for marks of the possible position of the theater to be found). Another important feature is the underground drainage pipeline passing through the Gymnasium, which is directed northeast to the potential location of the ancient theater. This pipeline might have been used to drain rainwater from the ancient theater.

Combined with the above structures (Temple and Gymnasium), the possible location of the ancient theater reveals a unique architectural ensemble of the ancient city, thus providing an indication of its existence.

For the acquisition of high-spatial-resolution images covering the potential location of the ancient theater, a drone was used.

\subsection{Flight Plan-Data Processing}

The flight height was set to $85 \mathrm{~m}$ above the terrain surface (the highest point of the study area), allowing the acquisition of high-spatial-resolution images with a Ground Sampling Distance (GSD) varying from 2 to $3 \mathrm{~cm}[32,37]$. The flight plan was realized by four flight strips with a forward overlap of $80 \%$ and a side overlap of $40 \%$ (Figure 5). In total, 56 images were acquired.

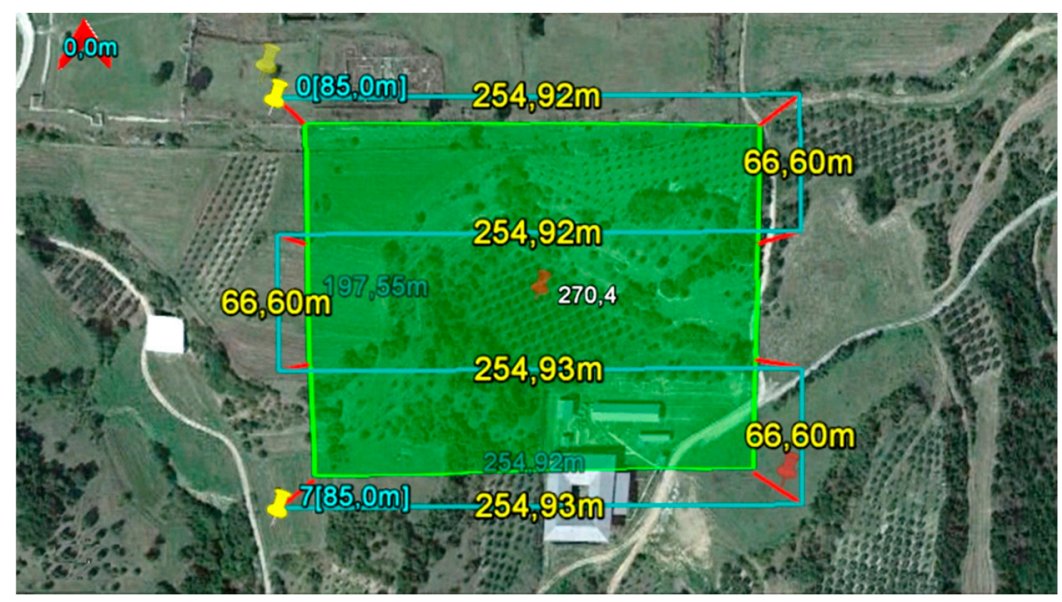

Figure 5. Drone flight plan.

Agisoft PhotoScan ${ }^{\circledR}$ software was used for the photogrammetric processing of the acquired images. The processing was realized using the Greek Geodetic Reference System 87 coordinate system (GGRS87 (EPSG:2100)). The first step was the automated alignment of the images using the "high accuracy" option in Agisoft PhotoScan ${ }^{\circledR}$ software.

For the generation of the point cloud, the "high quality" option was selected (to specify the desired reconstruction quality, and higher quality settings can be used to obtain more detailed and accurate geometry). At the stage of dense point cloud generation, Agisoft PhotoScan ${ }^{\circledR}$ calculates depth maps for every image. To sort out the outliers generated during the point cloud generation, Agisoft PhotoScan ${ }^{\circledR}$ has several built-in filtering algorithms. Since the area to be reconstructed does not contain meaningful small details, the "aggressive" depth filtering mode was selected to sort out most of the outliers. 
For the aerial triangulation, eight Ground Control Points measured with GPS in the GGRS87 coordinate system were used. The image overlap was $80 \%$, the image sidelap was $40 \%$, and the camera was well calibrated. Therefore, the internal geometry of the bundle was quite rigid and the eight GCPs were adequate for the exterior orientation. The GCPs were measured with a planimetric accuracy of 7-10 $\mathrm{mm}$ and a height accuracy of 9-17 $\mathrm{mm}$. The aerial triangulation was computed with an error of $0.048 \mathrm{~m}$.

For the mesh generation, the "height field" option was selected in the surface type option (The height field surface type is optimized for modeling planar surfaces, such as terrains or bas-reliefs). The dense point cloud was selected as source data (to specify the source for the mesh generation procedure), which thus generated a high-quality output based on the previously generated dense point cloud. Moreover, for the creation of the texture, the "orthophoto" option in mapping mode was selected (in this mode the whole surface of the object is textured in the orthographic projection). The "mosaic" option was selected in blending mode (which selects the way pixel values from different photos will be combined in the final texture), giving higher- quality orthophoto and texture atlases, since it does not mix image details of overlapping photos but rather uses the most appropriate photo. Finally, the Digital Surface Model (DSM), Digital Terrain Model (DTM), and ortho image of the study area were generated (Figure 6) with a spatial resolution of $3 \mathrm{~cm}$ [32].
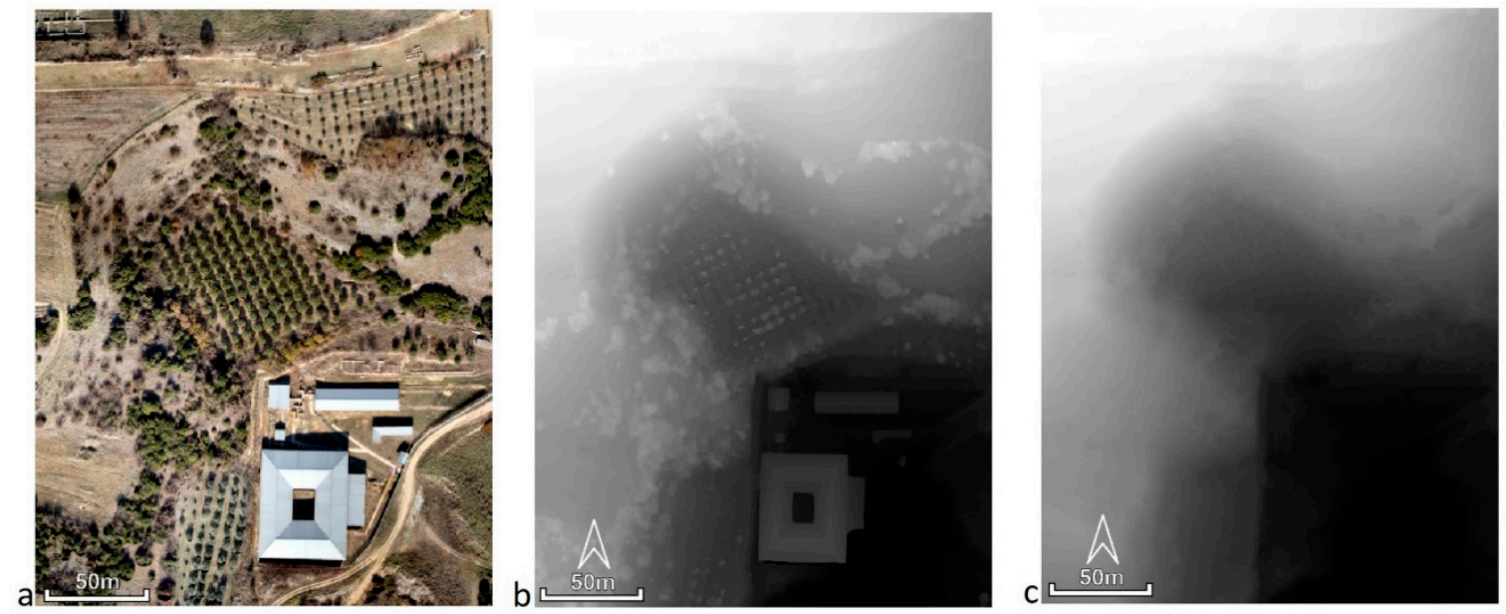

Figure 6. Photogrammetric processing results. (a) Orthorectified image; (b) Digital Surface Model (DSM); and (c) Digital Terrain Model (DTM). Height variation: 79.3 m (black)-123.5 m (white). Spatial resolution: $3 \mathrm{~cm}$.

\subsection{Determining the Probable Position of the Buried Theater's Orchestra Center}

Based on the assumption that the terrain relief follows the inclinations of the buried ancient theater's koilon, it is possible to determine the potential center of the buried theater's orchestra. The study of the contour lines, created using the DSM, provides an additional tool to be used in achieving this goal (Figure 7a). In the area of the contour lines that resembles the koilon morphology (Figure 7a,b), chords were placed randomly on each contour line. The vertical lines originating from the middle of the chords will theoretically intersect at the center of the buried theater's orchestra. In our study, the lines intersected at more than one point. As a result, the mean of all the intersection points was selected as the potential center of the orchestra. The absolute height of the selected point was $90.1 \mathrm{~m}$.

\subsection{Terrain Cross-Sections}

The nearest theater to Amphipolis is the theater of Philippoi, (approximately $55 \mathrm{~km}$ away), which is still standing today. Philippoi was an ancient city of Eastern Macedonia (Greece), and its location has been populated since the Neolithic era. Its history began in 360/359 B.C., when colonists from Thasos 
established the first city at that location, "Krinides". In 356 B.C., when the city was threatened by the Thracians, they asked for the help of Philippos II. Philippos II, realizing the economic and strategic importance of the city, occupied and fortified the city, renaming it Philippoi. The city flourished during both the Macedonian and Roman periods. Via Egnatia passed through the city [20]. Apostle Paul founded the first Christian church on European soil in this city. The ancient theater of the city goes back to times of the Macedonian king (in the middle of the fourth century B.C.) and it has the addition of an epitheater. It was surveyed in 2012 during test flights of an RC (Remote Control) Balloon [22]. Besides the acquisition of images (Figure 8a), Ground Control Points were also measured using a GPS receiver. The objective was the generation of a high-spatial-resolution orthorectified image (Figure $8 \mathrm{~b}$ ) and a DSM of the theater. The inclination of the theater's koilon is $42 \%$ based on the produced 3D model.
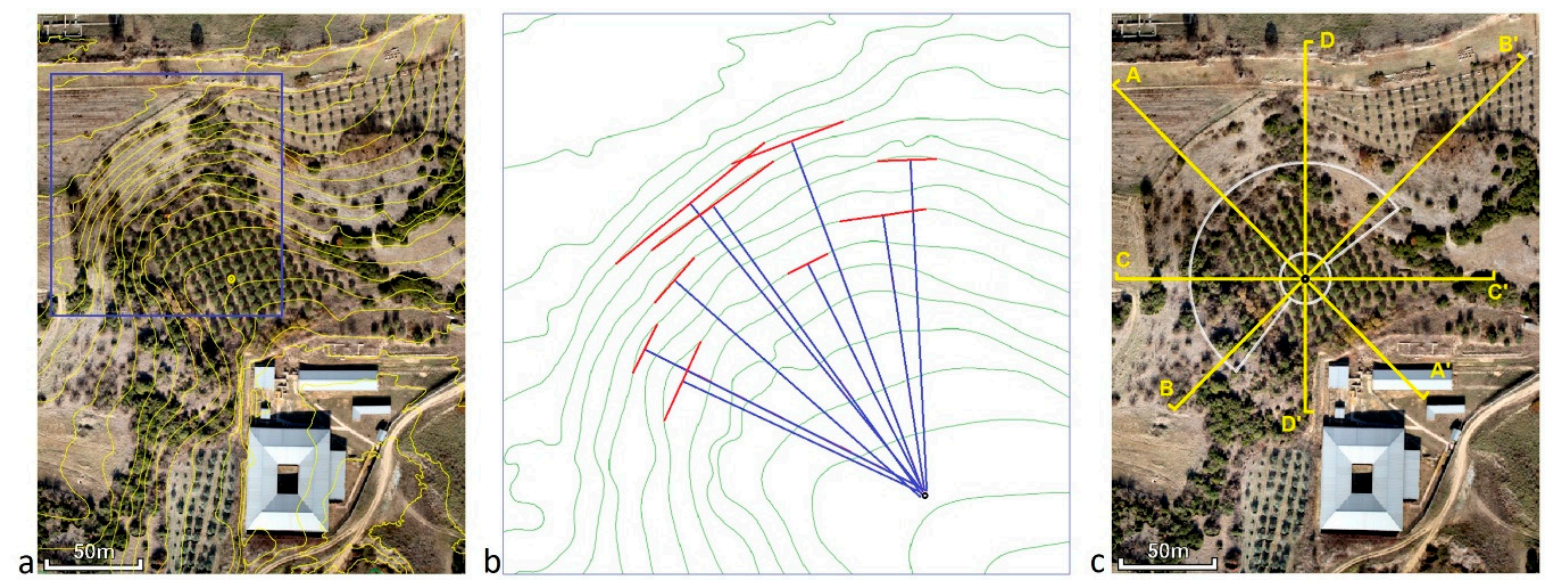

Figure 7. (a) The orthorectified image and the contour lines (colored yellow) with 2-m intervals. The blue rectangle denotes the area of the terrain relief that was used (b) for the determination of the potential center of the orchestra. (b) Contour lines (green), with the placement of a random number of chords (red) on each contour line. The vertical lines originating from the middle of the chords (blue) and the potential location of the center of the orchestra (black circle) are also shown. The potential center is also presented in $(\mathbf{a}, \mathbf{c})$. The potential location of the koilon and the orchestra are presented in white. The location of the cross-sections is presented in yellow.
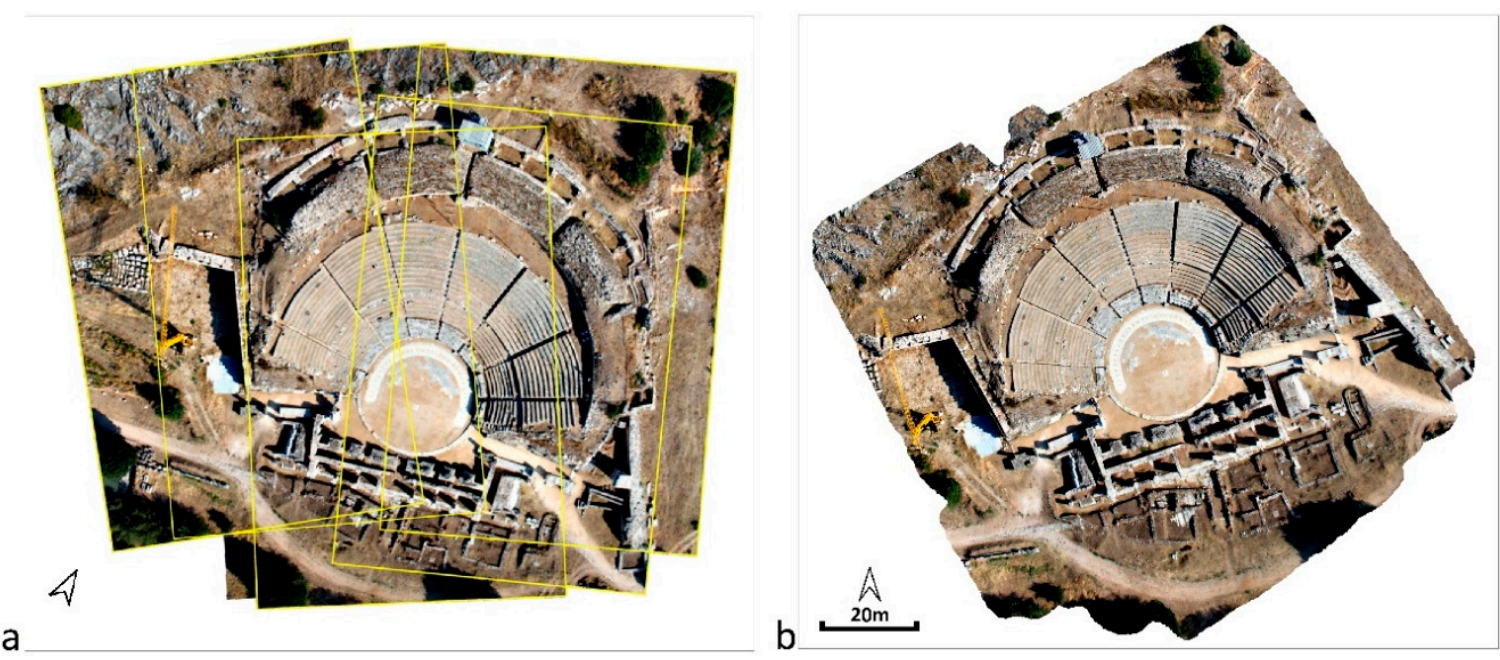

Figure 8. (a) The overlap of the 2012 images (spatial resolution: $1.5 \mathrm{~cm}$ ) acquired with an RC balloon at the location of Philippoi's ancient theater (personal archive). (b) The orthorectified image (spatial resolution: $3 \mathrm{~cm}$ ) of Philipoi's ancient theater (personal archive). 
Assuming that both theaters (the Amphipolis and Philippoi Theaters) have similar planimetric dimensions and height differences, the documentation of the dimensions (top view and height differences of its architectural parts) of the theater of Philippoi are used to study the potential location of the buried ancient theater of Amphipolis. Using the center (dimensions X and Y) of the orchestra, as identified above, the orientation and the absolute altitude of the orchestra (dimension $\mathrm{Z}$ ) underground were approximately chosen (Figures $7 \mathrm{c}$ and 9). The above shows that, through the following cross-sections, the ancient theater of Amphipolis could be located under the positions noted in study.

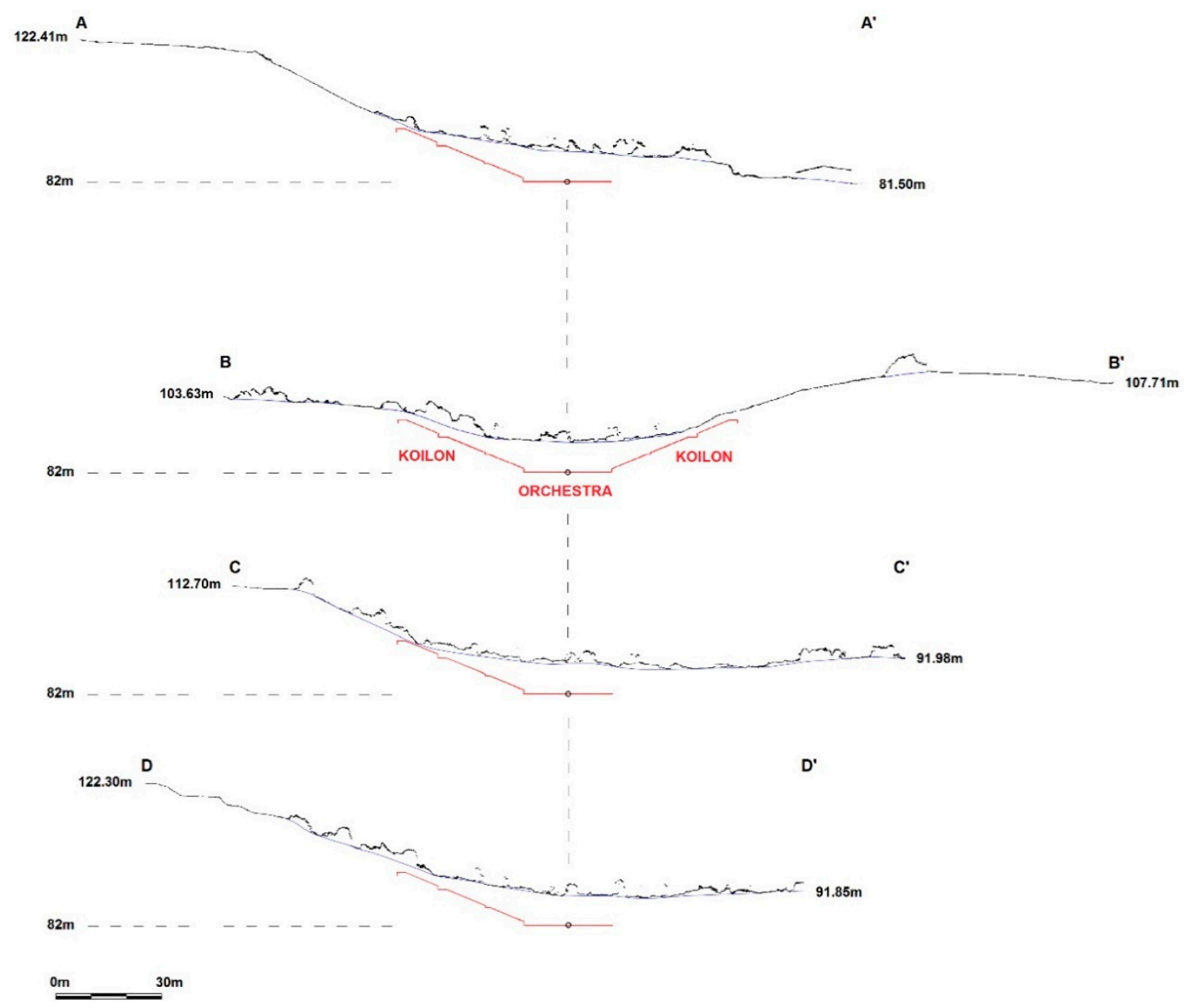

Figure 9. Cross-sections $\mathrm{AA}^{\prime}, \mathrm{BB}^{\prime}, \mathrm{CC}^{\prime}$, and $\mathrm{DD}^{\prime}$. The terrain model (Figure $6 \mathrm{c}$ ) is shown in blue, the surface model (Figure $6 \mathrm{~b}$ ) is shown in black. The approximate absolute height of the buried orchestra is $82 \mathrm{~m}$ (red circle). The intersection of the koilon and the orchestra is presented in red.

The AA' cross-section (Figures 7c and 9) bisects the buried theater's koilon. The highest point of the natural ground is $121.41 \mathrm{~m}$ (left, absolute height) and the lowest height of the natural ground is $81.5 \mathrm{~m}$ (right, in the vicinity of the Gymnasium and the Temple). The buried orchestra has an absolute height of $82.0 \mathrm{~m}$. The surface model is represented by a black line, which describes the cross-section of both the vegetation (trees and bushes) and the protective covers of the archaeological structures of the Gymnasium (right). It is obvious that at some sections the surface model is the same as the terrain model. The depth of the koilon and the orchestra ranges from $0.7 \mathrm{~m}$ to $8.1 \mathrm{~m}$.

The $\mathrm{BB}^{\prime}$ cross-section is perpendicular to the $\mathrm{AA}^{\prime}$ cross-section and intersects the two tiers as well as the ends of the koilon. The terrains located to the left and right of the cross-section have absolute heights of $103.63 \mathrm{~m}$ and $107.1 \mathrm{~m}$, respectively, while its lower level lies at $90.1 \mathrm{~m}$. The terrain relief 
follows the morphology of the buried theater across the length of the cross-section. The buried theater is placed at a depth ranging from $1.7 \mathrm{~m}$ to $8.1 \mathrm{~m}$.

In the $\mathrm{CC}^{\prime}$ cross-section, the theater is placed at a depth ranging from 0.4 to $8.1 \mathrm{~m}$, while in the $\mathrm{DD}^{\prime}$ cross-section it is placed in a depth ranging from $1.8 \mathrm{~m}$ to $8.1 \mathrm{~m}$. In both cross-sections, the terrain relief follows the geomorphology of the buried theater.

Therefore, if the ancient theater was oriented as shown in Figure $7 \mathrm{c}$ and the orchestra was located at an altitude of $82.0 \mathrm{~m}$ (absolute), it is possible that the position under study is identical to the position of the ancient theater, as the terrain follows its slope and shape.

\section{Conclusions}

It is obvious that the use of geo information tools such as multi-temporal orthorectified images and DTM combined with existing studies and oral testimonies allow for the discovery of the potential location of buried archeological sites. In this study, the potential location of the ancient theater of Amphipolis was determined by using and combining the available geospatial data (terrain relief, aerial and satellite images) with existing studies and testimonies of the area's residents.

Drones are a useful digital image acquisition platform that, when coupled with high-accuracy GCPs, can generate various high-resolution geospatial outputs. To determine the potential location of the ancient theater, the DSM, DTM, and ortho image of the study area were generated with a spatial resolution of $3 \mathrm{~cm}$. The generated outputs led to the determination of the orchestra's center by exploiting geometric design rules of ancient theaters and studying multiple terrain cross-sections in various directions within the area encompassing the potential location of the ancient theater. As a result, alternative scenarios can be generated for the dimensions, the orientation, and the accurate position of the ancient theater.

The methodological procedure that was followed in this paper could be used for other covered ancient theaters in Greece. However, this is not an easy task since we know very little regarding the location of covered ancient theaters based on existing texts. Furthermore, no testimonies or marks exists to point to a specific location. Finally, in addition it is very time-consuming to acquire permits from the Ministry of Culture and the Ephorate of Antiquities to study these areas.

In this study, the potential location of the ancient theater of Amphipolis was successfully determined, but an archaeological excavation of the site can only verify the generated results.

Author Contributions: All the authors contributed equally in this research.

Funding: This research received no external funding.

Conflicts of Interest: The authors declare no conflict of interest.

\section{References}

1. Kaimaris, D.; Patias, P.; Georgoula, O.; Karadedos, G. First thoughts about the location of the potential roads of "Nine Roads" (Amphipolis) with geoinformation tools. In Honorary Bookfor Emeritus Professor Ch. Kaltsikis; Ziti: Thessaloniki, Greece, 2016; pp. 239-251.

2. Jones, S.H. Thucydidis: Historiae Tomus Posterior, OXONII; E Typographeo Clarendonioano, Reprindet, Clarendon: Oxford, UK, 1970; pp. 100-108.

3. Baladie, R. Strabon Geographiae; In Tome IV (Livre VII); Les Belles Lettres: Paris, France, 1989; pp. $35-47$.

4. Godley, D.A. Herodotus; Mass Harvard University Press: Cambridge, MA, USA, 1921; p. 114.

5. Lazaridis, D. Amphipolis; Ministry of Culture: Athens, Greece, 1993; pp. 15-137.

6. Goukowsky, P. Diodore de Sicile; In Bibliotheque Historiogue Livre XVIII; Lew Belles Lettres: Paris, France, 1978; p. 4.

7. Karadedos, G.; Karadimas, C. Ancient Theater of Maronia. In Proceedings of the Archaeological Project in Macedonia and Thrace; Ministry of Culture-Archaeological Resources Fund: Thessaloniki, Greece, 2002; pp. 11-16. 
8. Banias, Z. The ancient theater of Thassos. In Book of the Ancient Theaters of Macedonia; Diazoma: Athens, Greece, 2012; pp. 225-244.

9. Karadedos, G.; Koukouli, X. The ancient theater of Philippi. In Book of the Ancient Theaters of Macedonia; Diazoma: Athens, Greece, 2012; pp. 193-215.

10. Kaimaris, D.; Georgiadis, C.; Patias, P.; Tsioukas, V. Aerial and Remote Sensing Archaeology. Int. J. Comput. Methods Herit. Sci. 2017, 1, 58-76. [CrossRef]

11. Gumerman, J.G.; Lyons, R.T. Archeological Methodology and Remote Sensing. Science 1971, 172, $126-132$. [CrossRef] [PubMed]

12. Guidi, G.; Russo, M.; Ercoli, S.; Remondino, F.; Rizzi, A.; Menna, F. A Multi-Resolution Methodology for the 3D Modeling of Large and Complex Archeological Areas. Int. J. Archit. Comput. 2009, 7, 39-55. [CrossRef]

13. Kucukkaya, G.A. Photogrammetry and remote sensing in archeology. J. Quant. Spectrosc. Radiat. Transf. 2004, 88, 83-88. [CrossRef]

14. López, J.B.; Jiménez, G.A.; Romero, M.S.; García, E.A.; Martín, S.F.; Medina, A.L.; Guerrero, J.E. 3D modelling in archaeology: The application of Structure from Motionmethods to the study of the megalithic necropolis of Panoria (Granada, Spain). J. Archaeol. Sci. Rep. 2016, 10, 495-506. [CrossRef]

15. Ely, J.C.; Graham, C.; Barr, I.D.; Rea, B.R.; Spagnolo, M.; Evans, J. Using UAV acquired photography and structure from motion techniques for studying glacier landforms: Application to the glacial flutes at Isfallsglaciären. Earth Surf. Process. Landf. 2017, 42, 877-888. [CrossRef]

16. Whitley, G.T. Unmanned Aerial Vehicles (UAVs) for Documenting and Interpreting Historical Archaeological Sites: Part II-Return of the Drones. Tech. Briefs Hist. Archaeol. 2015, 9, 41-48.

17. Green, S.; Bevan, A.; Shapland, M.A. Comparative Assessment of Structure from Motion Methods for Archaeological Research. J. Archaeol. Sci. 2014, 46, 173-181. [CrossRef]

18. Willis, D.M.; Charles, W.; Koenig, W.C.; Black, L.S.; Castañeda, M.A. Archeological 3D mapping: The structure from motion revolution. J. Tex. Archeol. Hist. 2016, 3, 31-33.

19. Kaimaris, D.; Georgiadis, C.; Georgoula, O.; Patias, P. Unmanned Aerial Vehicles and the Multi Temporal Mapping Results of the Dispilio Lakeside Prehistoric Settlement. In Advances in Digital Cultural Heritage; Ioannides, M., Martins, J., Žarnić, R., Lim, V., Eds.; Lecture Notes in Computer Science; Springer: Berlin, Germany, 2018; Volume 10754, pp. 1-14.

20. Kaimaris, D. Photogrammetric Processing of Digital Images in the Service of Archaeological Research: The Localization of Via Egnatia from Amphipolis to Philippi. Ph.D. Thesis, Aristotle University of Thessaloniki, Thessaloniki, Greece, 2006.

21. Stott, D.; Doreen, S.; Boyd, S.D.; Beck, A.; Cohn, G.A. Airborne LiDAR for the Detection of Archaeological Vegetation Marks Using Biomass as a Proxy. Remote Sens. 2015, 7, 1594-1618. [CrossRef]

22. Kaimaris, D.; Patias, P. A low-cost image acquisition system for the systematic observation of traces of buried archaeological structures. GEOMATICA 2014, 68, 299-308. [CrossRef]

23. Kaimaris, D.; Georgoula, O.; Karadedos, G.; Patias, P. Military trenches or Ancient Fortifications Constructions? AARGNews 2008, 36, 33-41.

24. Kaimaris, D.; Sylaiou, S.; Georgoula, O.; Patias, P. GIS of Landmarks Management. J. Cult. Herit. 2011, 12, 65-73. [CrossRef]

25. Kaimaris, D.; Georgoula, O.; Patias, P.; Stylianidis, E. Comparative analysis on the archaeological content of imagery from Google Earth. J. Cult. Herit. 2011, 12, 263-269. [CrossRef]

26. Kaimaris, D.; Patias, P.; Tsakiri, M. Best period for high spatial resolution satellite images for the detection of marks of buried structures. Egypt. J. Remote Sens. Space Sci. 2012, 15, 9-18. [CrossRef]

27. Georgoula, O.; Kaimaris, D.; Tsakiri, M.; Patias, P. From the aerial photo to high resolution satellite image. Tools for the archaeological research. In Proceedings of the International Archives of XXth ISPRS Congress: Geo-Imagery Bridging Continents, Istanbul, Turkey, 12-23 July 2004; ISPRS: Istanbul, Turkey, 2004; pp. 1055-1060.

28. Kaimaris, D.; Georgoula, O.; Karadedos, G. The locating of an Unknown Archaeological Site in the Valley of Philippi, Eastern Macedonia, Greece with the use of aerial photographs, satellite images and GIS. In Proceedings of the 36th Annual CAA (Computer Applications and Quantitative Methods in Archaeology) Congress: On the Road to Reconstructing the Past, Budapest, Hungary, 2-6 April 2008; CAA: Hungary, Budapest, 2008; pp. 42-50. 
29. Chodoronek, M. The Use and Application of Photogrammetry for the In-Field Documentation of Archaeological Features: Three Case Studies from the Great Plains and Southeastern Alaska. Master's Thesis, University of Nebraska-Lincoln, Lincoln, NE, USA, 2015.

30. Gospodinova, V.; Georgiev, P. An innovative technology for creating an orthophotoplan. J. Min. Geol. Sci. 2017, 60, 48-52.

31. Georgoula, O.; Kaimaris, D.; Karadedos, G.; Patias, P. Photogrammetry and Archaeology: A case study in the archaeological site of Philippoi in N. Greece. In Proceedings of the CAA (Computer Applications and Quantitative Methods in Archaeology) Congress: Enter the Past. The E-way into Four Dimensions of Cultural Heritage, Vienna, Austria, 8-12 April 2003; CAA: Vienna, Austria, 2003; pp. 409-413.

32. Kaimaris, D.; Patias, P.; Sifnaiou, M. UAV and the comparison of image processing software. Int. J. Intell. Unmanned Syst. 2017, 5, 18-27. [CrossRef]

33. Colomina, I.; Molina, P. Unmanned aerial systems for photogrammetry and remote sensing: A review. ISPRS J. Photogramm. Remote Sens. 2014, 92, 79-97. [CrossRef]

34. Anagnostoudi, A.; Theodorou, P. Inter Relations between Amphipolis and the Kingdom of Macedonia; Department of History and Archeology, Faculty of Philosophy, Aristotle University of Thessaloniki: Thessaloniki, Greece, 2014.

35. Papadopoulou, M.; Nikolaou, E. Necropolis of Amphipolis on the Amphipolis-Serres Road. Period 2011-2012; Department of History and Archeology, Faculty of Philosophy, Aristotle University of Thessaloniki: Thessaloniki, Greece, 2017.

36. Zikos, N. Amphipolis: Early Christian and Byzantine Amphipolis; Fund for Archaeological Resources and Expropriations: Athines, Greece, 1989.

37. Pepe, M.; Fregonese, L.; Scaioni, M. Planning airborne photogrammetry and remote-sensing missions with modern platforms and sensors. Eur. J. Remote Sens. 2018, 51, 412-435. [CrossRef]

(C) 2018 by the authors. Licensee MDPI, Basel, Switzerland. This article is an open access article distributed under the terms and conditions of the Creative Commons Attribution (CC BY) license (http:/ / creativecommons.org/licenses/by/4.0/). 